INDEPENDENT JOURNAL OF MANAGEMENT \& PRODUCTION (IJM\&P)

http://www.ijmp.jor.br V. 11, n. 5, Special Edition IFLOG 2019 -September 2020 ISSN: 2236-269X

DOI: 10.14807/ijmp.v11i5.1272

\title{
POTENTIAL BENEFIT FOR PRODUCTION MANAGEMENT OF A PULP AND PAPER COMPANY FROM USING AN FT-NIR ANALYZER
}

\author{
Eugenio De Felice Zampini \\ Instituto Federal de Educação, Ciência e Tecnologia de São Paulo \\ (IFSP), Brazil \\ E-mail: eugenio.zampini@ifsp.edu.br \\ William Akio Oliveira \\ Instituto Federal de Educação, Ciência e Tecnologia de São Paulo \\ (IFSP), Brazil \\ E-mail:williamakio20@gmail.com
}

Submission: 2/17/2020

Revision: $3 / 3 / 2020$

Accept: 3/6/2020

\section{ABSTRACT}

The pulp and paper segment has been seeking to increase mill efficiency through cost reduction and better production management. One of the ways to achieve this goal is through better control and operation of the pulp plant digester cooking. The study aimed to verify the accuracy of the FT-NIR analyzer in the liquor lines of a pulp and paper digester and its possible benefits for production management. The research methodology used was the case study, where it was analyzed and compared the results of the equipment with the values of the company's laboratory. The analysis of the instrument proved accurate and reliable, providing information on various properties of liquors that enable the optimization of production management with the stabilization of the operation. Future trends indicate that infrared technology will continue to play an important role as a detection platform due to its inherent flexibility and capability.

Keywords: Production management; FT-NIR analyzer; Pulp and Paper. 
DOI: 10.14807/ijmp.v11i5.1272

\section{INTRODUCTION}

The pulp and paper industry faces a constant challenge to control and manage its production in order to keep it stable and close to the ideal, seeking new technologies and improvements. Favaretto (2001) points out that among these improvements, there is the search for a high efficiency of productive resources, as a way of maximizing operational income.

Companies in this industrial segment have been seeking to increase the efficiency of factories by reducing production costs (RESTREPO et al., 2009), and one of the ways to achieve this goal is through better control and operation of the cooking that took place in the digester of the cellulose plant.

Cooking consists of subjecting the chips, which are made up of lignin, hemicellulose and cellulose to a chemical action of strong white liquor (a mixture of caustic soda and sodium sulfide) and water vapor. Inside the digester, lignin is dissolved between fibers. The digester is a pressure vessel, with an approximate $60 \mathrm{~m}$ height, where the chips and strong white liquor are continuously introduced from the top (RESTREPO et al., 2009). Then the weak black liquor is formed by the mixture of the white liquor with the dissolved lignin from the chips.

In the current Kraft cooking process, alkaline measurements are used to determine the consumption of chemicals during the different cooking phases. These measurements are widely accepted as standard monitoring information, as they provide a solid basis for managing the operation of the digester. As such, to optimize the operation of the digester, concentrations of white liquor and effective residual alkali (ERA) of black liquor are required in the various cooking zones.

By monitoring the effective alkali of the white liquor, as well as the sulfidity online and knowing the moisture content of the wood, the correct ratio between the liquor and the wood can be controlled (LOMBARDI and LUIZ, 2017). In addition, by measuring the ERA in various areas of the digester, faster feedback will be available regarding the rate of alkali consumption and adjustments can be made to compensate for changes in the properties of the wood.

Knowledge of ERA in all cooking zones would provide better control of the kappa through cooking in the digester, thereby reducing overcooking or undercooking. Ultimately, for Silva et al. (2016), the income gains could be realized together with the lower kappa variability due to the possibility of a more stable production control. The kappa number, 
DOI: 10.14807/ijmp.v11i5.1272

according to the ABNT NBR ISO 302: 2018 standard, is "an indication of the residual lignin content or of the cellulose pulp's whitening capacity”.

The study in question involves the first equipment using FT-NIR (Fourier Transform Near Infrared) technology that was installed in South America, making it possible to obtain accurate and real-time analyzes of liquor properties, which is why it is a justified research in this area. The study aimed to verify the accuracy of the FT-NIR analyzer in the liquor lines of a digester of a paper and cellulose company and its possible benefits for the production management. The research methodology used was the case study.

The subsequent sections present the literature review, methodology, analysis of results and discussion, and conclusions, respectively.

\section{LITERATURE REVIEW}

In today's globalized economy, the survival of organizations depends on their ability and speed to innovate and make continuous improvements. As a result, organizations are constantly looking for new management tools that will lead them to greater competitiveness through the quality and productivity of their products, processes and services (OTANI and MACHADO, 2008).

In order to achieve an efficient cost management and, mainly, to follow the dynamics of changes in the supplier and consumer markets, in addition to knowing the costs, a constant search for reduction and continuous improvement of costs is essential for the company (POMPERMAYER and LIMA, 2002 ).

However, without reliable information from the process, this type of management becomes costly and difficult. Until then, the measuring instruments installed in the cooking process of the cellulose digester in plants in Brazil are imprecise and require constant maintenance, or use a large amount of chemicals, as is the case with the titration records. The FT-NIR measurement technology, in addition to avoiding these problems, measures several parameters present in the analyzed substances.

Infrared spectroscopy (near-infrared) has been shown as a means for the rapid nondestructive determination of the chemical composition (liquors) and the final yield of the pulp (TERDWONGWORAKUL et al., 2005). Infrared, together with the Fourier transform, is an essential analytical tool for the structural analysis of the chemistry of paper and cellulose. 
DOI: 10.14807/ijmp.v11i5.1272

Fourier transform infrared spectroscopy (FTIR), according to Faix (1992), can be applied in specialized areas in microanalysis where great sensitivity is required in the analysis of aqueous or dark solutions and even in solid samples that require the use of a technique special reflectance for determining quantity and in cases where recognition has time as a limiting factor.

Many researchers have reported that the NIR (near-infrared) technique was useful for detecting multiple information on the chemical and physical properties of wood materials (TSUCHIKAWA, 2007). Moreover, this can contribute to the reduction of several factors that have an impact on the daily production of paper, as mentioned by Duran and Fardim (2007), who point to calcification in the measuring terminals of conditivimeters and densimeters as the main causes of errors in measurements obtained in the process. In addition, according to Duggirala (2005) and Grace and Tran (2007), the accumulation of scale in the kraft digester and black liquor evaporators is a major contributor to the loss of productivity at the pulp mill.

Cruz et al. (2006) still say that these particles are deposited in various parts of the factory's machines and are responsible for reducing production, increasing the cost of maintaining and operating the equipment and increasing defects in the final product and consequently reducing its quality. "During industrial processes, a lot of waste is generated, which can be of solid, liquid or gaseous origin” (ALMEIDA et al., 2007).

The main advantage of the application of the FT-NIR analyzer in the digester is its ability to provide the information of Effective Alkali (EA) of the white liquor and sulfidity, as well as the ERA of the black liquor in the various zones, in a reliable and accurate way. Trung and Allison (2012) state that the control strategy based on reliable data can significantly reduce kappa variation, overcooking and tailings, while increasing the quality of the pulp. Still, according to the same authors, the reduction of kappa variability can also have a significant reduction in bleaching costs and, as a result, improvement in yield is possible. Forsström et al. (2006) highlight that the optimal cooking kappa is a versatile tool for improving the financial development of an eucalyptus cellulose plant.

It is also worth remembering that this more precise control and management of production is not done in the pulp and paper companies because there are no accurate and realtime measurements. However, this scenario will tend to change with the results of this first installation of the FITNIR analyzer in South America, which is the object of study in this work.

\section{METHODOLOGY}


DOI: 10.14807/ijmp.v11i5.1272

For the development of the research, investigation strategies were implemented, such as bibliographic material survey and analysis, collection of process data, installation of infrared equipment, collection of new process information and, finally, study and comparison of elements obtained.

Initially, a bibliographic survey was carried out with the purpose of investigating the current applications of infrared in industrial plants, focused on the paper and cellulose segment, the main difficulties in production management involving the industry digester and the main benefits pointed out in studies on the most stable operation based on parameters such as sulfidity and kappa.

In the second step, infrared equipment was installed in the liquor lines of the digester through tie-ins in the local piping of a paper and cellulose company. The analyzer is from a Canadian company called FITNIR. Then, the new information was collected and analyzed, as well as laboratory tests after implantation of the device.

In order to assess the accuracy of the FT-NIR equipment and to obtain comparison parameters, the results of laboratory tests of the company's liquors were gathered. These samples were collected at an extraction point, which is present in the equipment by the company's professionals, at the same time that the instrument performed the analysis of the liquors, thus allowing a correlation between the results.

All values of EA (effective alkali), AA (active alkali), TTA (total treatable alkali), among others, were analyzed by the Research and Development team, following the company's standard procedures. Inorganic solids were calculated from the difference between total and organic solids. In total, 103 samples of white and black liquors were collected and analyzed, with the results obtained by the laboratory and equipment compared.

Subsequently, all the elements achieved with this research were analyzed and compared, and from there, possible gains that the use of infrared technology can bring to the industrial paper and cellulose market were evaluated.

Finally, the results and conclusions of the research were systematized in the form of writing.

\section{RESULTS, ANALYSIS AND DISCUSSION}

\subsection{Overview of the process}


DOI: 10.14807/ijmp.v11i5.1272

The cooking area (Figure 1) consists of the chip feeding system, an impregnation vessel and digester. The equipment of the Canadian company, FITNIR, was installed close to the process so that six sampling points were taken from the licensing lines.

One point of analysis is for white liquor and the remaining points comprise black liquors that involve each stage of the digestion process: upper circulation, lower circulation, extraction, bottom circulation and transfer.

The liquors are taken through 1/2” 316L stainless steel pipes to the field equipment, called FSS (Field Sampling Station). The lamps are incidents with infrared light and the information is carried through the optical fiber to the SRS (Spectrometer Rack System). All parameters of the licensees' properties are analyzed and forwarded to the company's DDCS (Digital Distributed Control System).

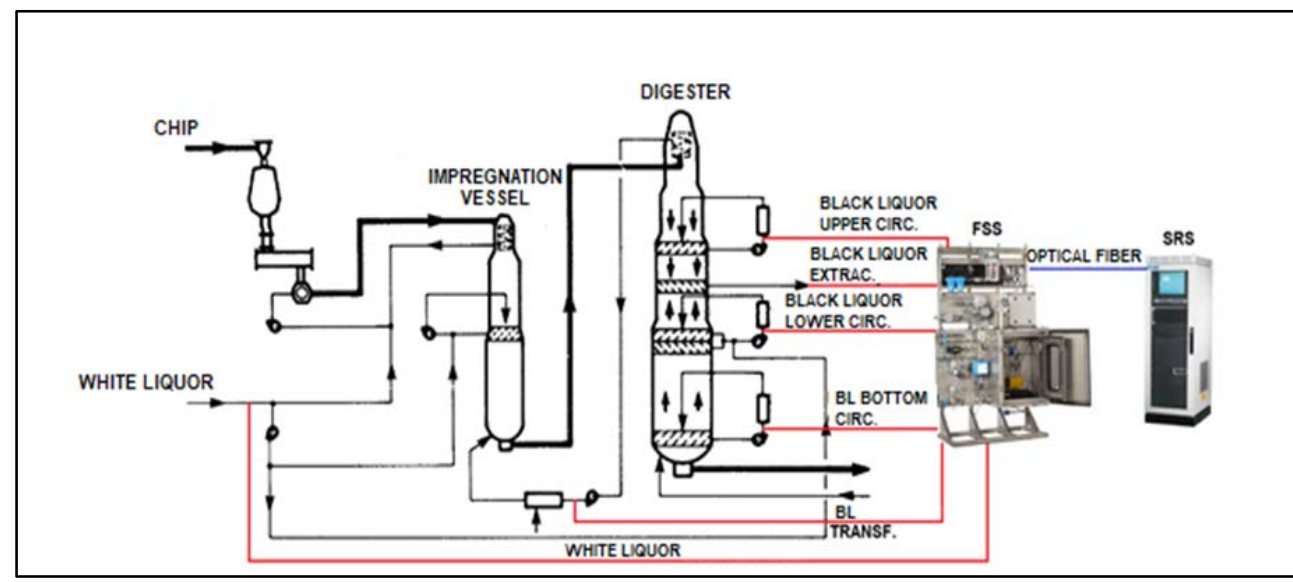

Figure 1: General Schematic of the Process

As a resource for the cooking operation, the area does not have an advanced supervisory control (APC - Advanced Process Control). The control is currently done by the operators, but it is expected to implement an APC for the automatic control of the operation with the approval and proof of the functioning of the FITNIR analyzer.

\subsection{Measurement of liquor properties}

For analysis of the composition of liquors, the table below shows the parameters considered for each type of liquor, as well as their description.

Table 1: Measurement of liquors from the FT-NIR analyzer

\begin{tabular}{|l|l|}
\hline Liquor & Measurements \\
\hline White Liquor & EA, AA, TTA, $\mathrm{Na}_{2} \mathrm{CO}_{3}, \mathrm{Na}_{2} \mathrm{~S}, \mathrm{Na}_{2} \mathrm{SO}_{4}, \mathrm{Na}_{2} \mathrm{~S}_{2} \mathrm{O}_{3}, \% \mathrm{~S}, \% \mathrm{CE}$ \\
\hline Black Liquor & ERA, Organic, Inorganic \& Total Solids \\
\hline Weak Black Liquor & TTA, Lignin, $\mathrm{NaOH}, \mathrm{Na}_{2} \mathrm{SO}_{4}, \mathrm{Na}_{2} \mathrm{~S}_{2} \mathrm{O}_{3}$ \\
\hline EA = Effective Alkali & $\mathrm{Na}_{2} \mathrm{CO}_{3}=$ Sodium Carbonate \\
AA = Active Alkali & $\mathrm{Na}_{2} \mathrm{~S}=$ Sodium Sulfide \\
TTA = Total Titratable Alkali & $\mathrm{Na}_{2} \mathrm{SO}_{4}=$ Sodium Sulfate \\
\hline
\end{tabular}


DOI: 10.14807/ijmp.v11i5.1272

\begin{tabular}{l|l}
\hline \%S = Sulfidity (\%) & $\mathrm{Na}_{2} \mathrm{~S}_{2} \mathrm{O}_{3}=$ Sodium Thiosulfate \\
$\% \mathrm{NE}$ = Causticizing Efficiency (\%) & $\mathrm{NaOH}=$ Sodium Hydroxide
\end{tabular}

The data for the analysis of black liquors made by the company's laboratory and the equipment are presented in the graphs with the results obtained.

Figures 2, 3, 4 and 5 show the graphic results of black liquors for the parameters of effective residual alkali (ERA), total solids, lignin and organic solids respectively.

The graphs on the left (Actual vs. Predicted) compare the values provided by the FITNIR equipment with the values provided by the Canadian manufacturer company when using its own database with information collected in several companies around the world in its more than 20 years of operation in the paper and cellulose market. A determination coefficient, also called $\mathrm{R}^{2}$, is presented as a measure of adjustment of the generalized linear statistical model, in relation to the observed values.

The graphs on the right (Lab vs. FITNIR) compare the values provided by the FITNIR equipment with the values analyzed by the company's laboratory. In addition, in addition to presenting the determination coefficient, they present the RMSEP (Root Mean Square Error of Prediction), as it is the simplest and most efficient measure of uncertainty in NIR (Near Infrared) predictions. This value is a measure of the average uncertainty that can be expected when predicting new samples. The RMSEP is expressed in the same units as the predicted parameter. The results of future analyzes can then be presented as predicted values $\pm 2 \mathrm{x}$ RMSEP. This measure is valid as long as the new samples are similar to those used for calibration, otherwise the forecast error can be much larger.

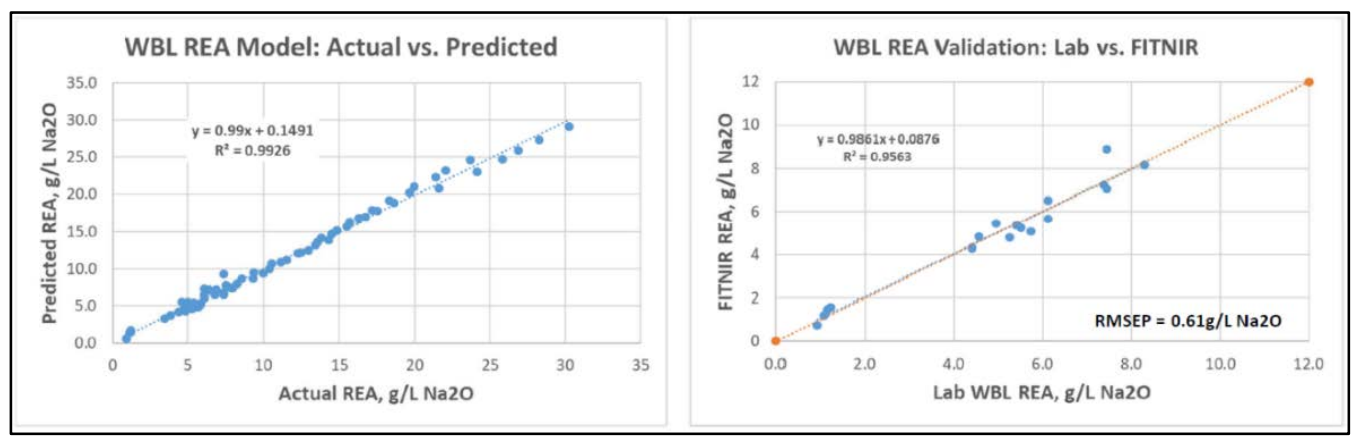

Figure 2: Graphical analysis for the Effective Alkali Residue of black liquor 
DOI: 10.14807/ijmp.v11i5.1272

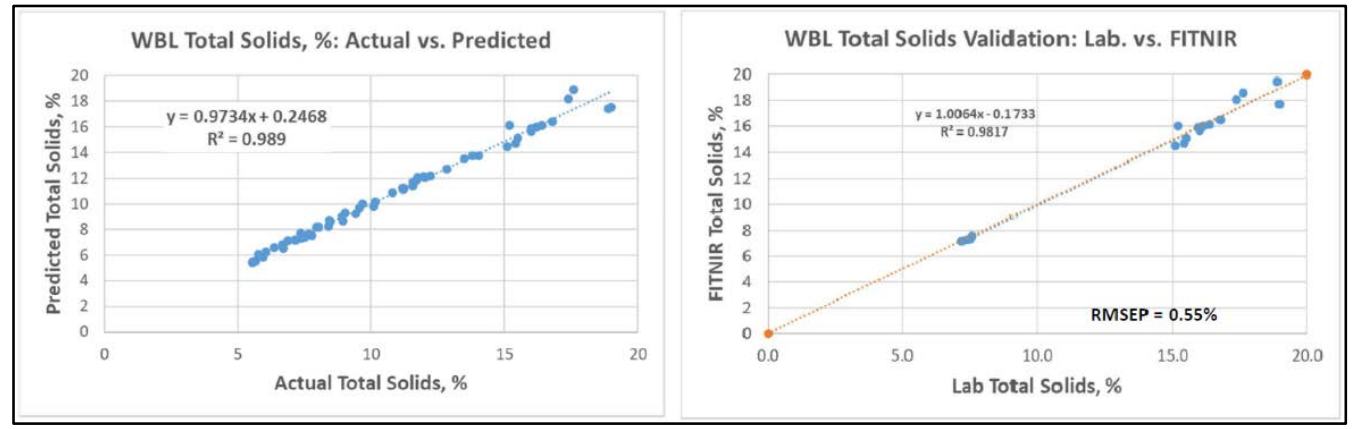

Figure 3: Graphical analysis for total solids of black liquor

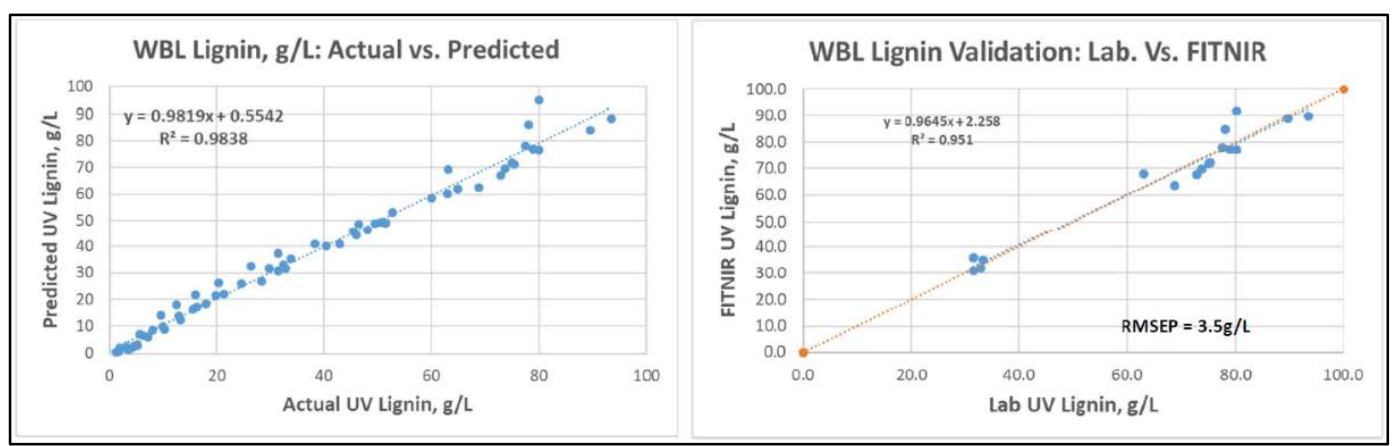

Figure 4: Graphical analysis for black liquor lignin

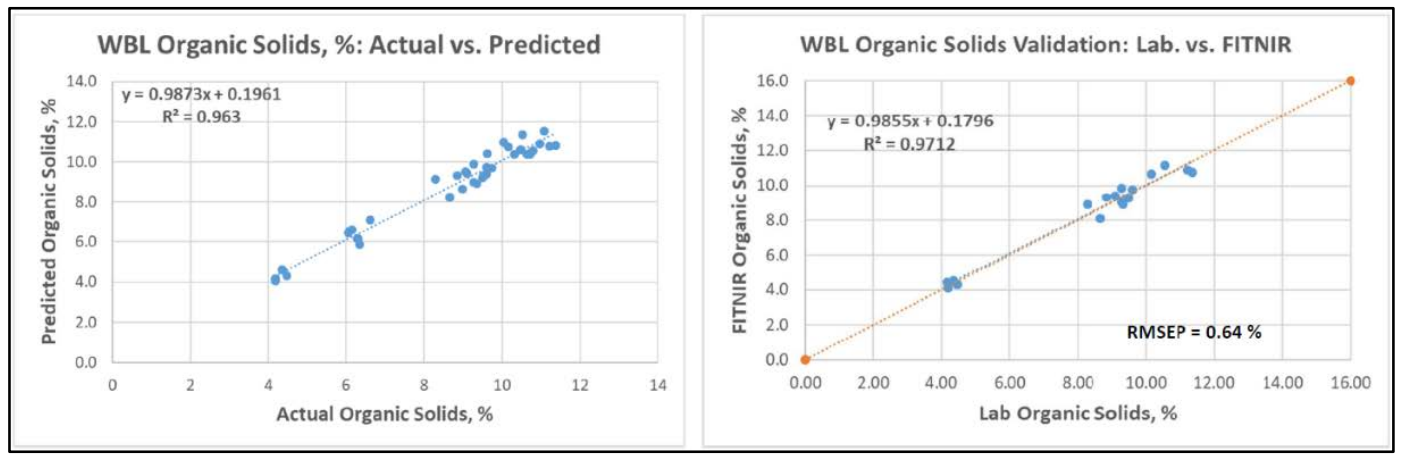

Figure 5: Graphical analysis for black liquor organic solids

In general, it was observed that the measurement results of the FITNIR equipment are close to those found in the laboratory, showing a good correlation $\left(\mathrm{R}^{2}>0.95\right)$ and acceptable RMSEP values (values above those obtained through current instruments).

Table 2 shows the data for laboratory and equipment measurements for white liquor. Again, some values were omitted for reasons of confidentiality; however, the main parameters that make up this study are as follows.

Once again, the results are as expected, showing great approximation between the values and enabling a more efficient management of the process. Management that involves the reduction of chemicals used, better performance of the equipment for the certainty of the good execution of the process, less maintenance and rework and so on. 
DOI: 10.14807/ijmp.v11i5.1272

Table 2: Results of white liquor

\begin{tabular}{|c|c|c|c|c|c|c|c|c|c|c|c|c|c|}
\hline \multicolumn{14}{|c|}{ WHITE LIQUOR } \\
\hline \multicolumn{7}{|c|}{ Lab Results as g/L NaOH } & \multicolumn{7}{|c|}{ FITNIR Results as g/L NaOH } \\
\hline EA & $A A$ & TTA & Carbonate & Sulfide & Sulfidity (\%) & $\mathrm{CE}$ & EA & AA & TTA & Carbonate & Sulfide & Sulfidity (\%) & $\mathrm{CE}$ \\
\hline 115,0 & 139,5 & 157,1 & 17,6 & 48,9 & 31,1 & 88,8 & 115,4 & 138,2 & 158,2 & 18,4 & 48,0 & 30,3 & 88,3 \\
\hline 114,9 & 139,3 & 155,7 & 16,4 & 48,9 & 31,4 & 89,4 & 114,5 & 137,8 & 153,3 & 15,2 & 49,1 & 32,1 & 90,1 \\
\hline 111,9 & 136,2 & 155,3 & 19,2 & 48,6 & 31,3 & 87,7 & 110,5 & 134,8 & 153,0 & 17,9 & 50,0 & 32,7 & 88,3 \\
\hline 111,8 & 136,7 & 153,3 & 16,6 & 49,7 & 32,4 & 89,2 & 113,6 & 136,9 & 154,6 & 17,4 & 49,2 & 31,8 & 88,8 \\
\hline 114,3 & 140,2 & 156,4 & 16,2 & 51,9 & 33,2 & 89,7 & 113,9 & 138,5 & 155,9 & 17,1 & 51,8 & 33,2 & 89,1 \\
\hline
\end{tabular}

Based on precise analyzes like these, it is possible to carry out a stable control of the kappa, with increased sulfidity and reduced demand for chips for the same pulp production rate. This better production management implies the growth of gross income, which represents tons of wood saved annually.

A more stable white liquor leads to less variation in the liquor load ratio (effective alkali) per wood, which points to a more stable kappa and higher digester yield. A more concentrated white liquor reduces its demand and the solids formed in the digester process, providing a better black liquor as a result.

Although not measured by work, it is conceptually mentioned that the stability of the kappa number at the digester outlet provides great economic gains, in addition to causing improvements in the following production processes.

\subsection{Optimization of operation and control}

The FITNIR analyzer provides information about the process, but alone can only provide monitoring through the analyzed data. The process control strategies need to be integrated with the measurements to obtain the expected and estimated returns in this study, in addition to good production management practices. Moreover, with that, it provides incentives for further industrial development.

\section{CONCLUSION}

The pulp and paper mills have been aiming to improve operating results with greater efficiency in the entire production system. Applications using FT-NIR spectroscopic techniques can contribute significantly to the achievement of this objective.

Online measurement of key process variables in the digester promotes opportunities to optimize its management with less variation in actual production compared to the target set and significant reductions in operational interventions in the cooking process.

In addition to the tangible gains pointed out in this and other studies, such as financial gains and several management and control opportunities, the use of the equipment in the liquor 
DOI: 10.14807/ijmp.v11i5.1272

lines leads to intangible gains such as: less maintenance (robust instrument), elimination of chemical consumption and reagents, offering multi-component measurements quickly and accurately, ideal for monitoring the process.

As this is the first project with the use of FT-NIR technology in South America, more studies are needed, but the results obtained show the tendency that infrared technology will continue to play an important role as a detection platform due to its inherent flexibility and capacity and, combined with advanced control, becomes a stepping stone for industry 4.0.

\section{REFERENCES}

ALMEIDA, H. C.; SILVEIRA, C. B.; ERNANI, P. R.; CAMPOS, M. L.; ALMEIDA, D. (2007) Composição Química de um Resíduo Alcalino da Indústria de Papel e Celulose (DREGS). Química Nova, v. 30, n. 7, p. 1669-1672.

CRUZ, M. P.; BARBOSA, L. C. A.; MALTHA, C. R. A.; GOMIDE, J. L.; MILANEZ, A. F. (2006) Caracterização Química do "Pitch” em Indústria de Celulose e Papel de Eucalyptus. Química Nova, v. 29, n. 3, p. 459-466.

DUGGIRALA, P. Y. (2005) Formation of Calcium Carbonate Scale and Control Strategies in Continuous Digesters. CD del II Coloquio Internacional sobre Celulosa de Eucalipto.

DURAN, N; FARDIM, P. (2007) Molecular Assembly in Kraft Pulping of Eucalyptus. Repositório da Produção Científica e Intelectual da UNICAMP, v. 68, n. 8, p. 98-108.

FAIX, O. (1992) Fourier Transform Infrared Spectroscopy. In: Lin S.Y., Dence C.W. Methods in Lignin Chemistry. Springer Series in Wood Science. Springer, Berlin, Heidelberg. p. 83-109.

FAVARETTO, F. (2001) Uma contribuição ao processo de gestão da produção pelo uso da coleta automática de dados de chão de fábrica. Tese de doutorado. Escola de Engenharia de São Carlos, Universidade de São Paulo.

FORSSTRÖM, A.; BASTA, J.; BLOM, C. (2006) Kappa ótimo de cozimento-uma ferramenta versátil para a melhoria do desenvolvimento financeiro de uma planta de celulose de eucaliptos. O Papel, v. 67, n. 6, p. 96-100.

GRACE, T. M.; TRAN, H. (2007) The effect of dead load chemicals in the kraft pulping and recovery system. Engineering, Pulping and Environmental Conference, TAPPI. 3, p. 2031-2064.

LOMBARDI, L. R.; LUIZ, A. C. (2017) Avaliação da Sulfidez do Licor Branco na Qualidade da Celulose Kraft. O PAPEL, v. 78, n. 7, p. 76-80.

OTANI, M.; MACHADO, W. V. (2008) A Proposta de Desenvolvimento de Gestão da Manutenção Industrial na Busca da Excelência ou Classe Mundial. Revista Gestão Industrial, v. 4, n. 2, p. 1-16.

POMPERMAYER, C. B.; LIMA, J. E. P. (2002) Gestão de custos. Finanças empresariais. Coleção Gestão Empresarial, Associação Franciscana de Ensino Senhor Bom Jesus. n. 4, p. 49-68. 
RESTREPO, A.; YUZAK, E.; RODRIGUES, L. A.; AFFONSO, R.; GEDRAITE, R. (2009) Considerações práticas acerca da aplicação de sistemas híbridos de controle avançado na indústria de celulose. O Papel, v. 70, n. 12, p. 35-51.

SILVA, M. A. A.; LIMA, R. A.; VENTORIM, L.; FERREIRA, C. R. S.; SARCINELLI, J.; AGUILAR, R. M.; MONFARDINI, M. A. (2016) Os Benefícios da Estabilidade da Descarga de Polpa do Digestor para o Processo de Cozimento - Estudo de Caso. O Papel, v. 77, n. 2, p. $72-80$.

TERDWONGWORAKUL, A.; PUNSUWAN, V.; THANAPASE, W.; TSUCHIKAWA, S. (2005) Rapid assessment of wood chemical properties and pulp yield of Eucalyptus camaldulensis in Thailand tree plantations by near infrared spectroscopy for improving wood selection for high quality pulp. Journal of Wood Science, v. 51, n. 2, p. 167-171, doi: 0.1007/s10086-004-0633-3

TRUNG, T.; ALLISON, B. (2015) Advanced Online Process Analyzer for Chemical Recovery and Pulp Mill Control. O Papel, v. 76, n. 1, p. 47-56.

TSUCHIKAWA, S. A. (2007) Review of Recent Near Infrared Research for Wood and Paper. Applied Spectroscopy Review Journal, v. 42, n. 1, p. 43-71. 